\title{
Notícias/News
}

\section{CINQUENTENÁRIO DO CURSO DE NUTRIÇÃO DA FACULDADE DE SAÚDE PÚBLICA DA UNIVERSIDADE DE SÃO PAULO.}

Em 1989, comemora-se o Cinqüentenário do Curso de Nutrição da Faculdade de Saúde Pública da Universidade de São Paulo. Em 24 de outubro de 1939, pelo Decreto Estadual n? 10.617, foi criado o Primeiro Curso de Nutrição do Brasil, pelo Prof. Geraldo Horácio Paula Souza.

Naquela época, o mundo vivia momentos de tensão e instabilidade devido ao início da II Guerra Mundial. No Brasil, Getúlio Vargas nomeava Adhemar de Barros interventor federal no Estado de São Paulo. Era um período em que predominavam os padrões europeus, conduzindo os jovens do sexo masculino ao estudo da Medicina ou do Direito e as moças à área de Filosofia e Letras.

Em meio a esse ambiente foi que o Prof. Paula Souza, educador sanitário e participante de um núcleo de Saúde Pública nos Estados Unidos, voltou do exterior com a convicção e o firme propósito de criar um Curso de formação de Nutricionistas, a fim de atuar na área de alimentação e nutrição.

No início, o curso foi estruturado com a duração de um ano em tempo integral, podendo matricular-se somente educadores sanitários.

Em 1962, por força do Parecer 50/62 do MEC, os Cursos de Nutrição do País passaram a ser de nível superior. De 1964 a 1966 o Curso de Nutrição da Faculdade de Saúde Pública foi interrompido para reformulação curricular e, em 1967, foi reaberto nos moldes do currículo exigido pelo MEC, com 3 anos de duração. Posteriormente, em 1972, passou a ser ministrado em 4 anos, sempre em tempo integral. Até 1983 oferecia vinte vagas e, a partir de 1984, esse número foi ampliado para 40 , preenchidas mediante concurso vestibular pela FUVEST.

Atualmente, Curso de Nutrição apresenta um currículo de $3.720 \mathrm{~h}$, distribuídas entre disciplinas básica e profissionalizante. Essa carga horária, além de atender ao Currículo Mínimo exigido pelo MEC, é complementada com disciplinas ou áreas afins, visando sempre melhor capacitar o profissional para atuar no mercado de trabalho.

O Curso serviu de modelo para duas impor- tantes conferências da Organização Mundial da Saúde (OMS) e Organização Pan-Americana da Saúde (OPAS) sobre treinamento de nutricionistas para a América Latina. Uma foi em Caracas (1966) e outra foi em São Paulo (1973).

Tendo em vista esses rápidos recortes no tempo, não se poderia deixar de comemorar o Cinqüentenário do Curso de Nutrição.

Para tais comemorações, foram previstas várias atividades.

8/8 - Abertura, com homenagem a vários nutricionistas que se destacaram no exercício profissional, iniciando implantação e organização de serviços de alimentação e nutrição em grandes hospitais, como, por exemplo, o Hospital das Clínicas da Faculdade de Medicina da Universidade de São Paulo, São Paulo, indústrias, programas de merenda escolar, etc. Nesta mesma data, foi descerrada a placa comemorativa e lançados o selo do cinqüentenário e o concurso direcionado a estudantes de Nutrição de todo o País, abordando o tema: "Alimentação equilibrada para o brasileiro hoje: mito ou realidade"'. Paralelamente, houve exposição de documentos históricos referentes ao Curso.

17/8 - Lançamento de material educativo sobre alimentação e nutrição, elaborado pelos alunos do Curso da Faculdade de Saúde Pública e destinados à Comunidade.

13/9 - Conferência: "O papel do nutricionista na sociedade moderna", proferida pelo Prof. Fernando José de Nóbrega, seguida de Painel sobre "O nutricionista e suas áreas de atuação", abordando os temas: informática, planejamento, saúde pública e nutrição clínica.

14/9 - Continuação do painel, enfocando: serviço de alimentação em indústrias, assessoria e consultoria, marketing, consultório dietético e atendimento ao consumidor.

24/10 - Encerramento das atividades, com entrega do prêmio "Cinqüentenário do Curso de Nutrição". 